\title{
Strengthening Consumer Protection Regulations in Indonesia as The Center and Global Halal Business Sector (Comparison of Health Law, Food Law, Consumer Protection Law and Halal Label)
}

\author{
Desty Anggie Mustika ${ }^{1}$, Zudan Arief Fakrulloh ${ }^{2}$ \\ \{desty@uika-bogor.ac.id ${ }^{1}$, cclsis@yahoo.com²
}

Universitas Borobudur, Jakarta, Indonesia ${ }^{1,2}$

\begin{abstract}
The COVID-19 disaster, which has been proclaimed by the World Health Organization a pandemic, isn't only an unadulterated medical problem, yet doesn't cover all viewpoints that would debilitate the financial system. The work to shape the world to contain the spread of this pestilence is by friendly removing in Indonesia. These efforts are beneficial on the one hand, but also result in a reduction in the supply of food raw materials as a whole, more or less the impact of the Covid-19 pandemic is very large, and can affect economic progress, especially in Indonesia. Health is certainly very important for today's society, including the consumption and purchase of products that are guaranteed cleanliness and halal raw materials. Therefore, during the COVID19 pandemic, halal products will occupy a major market position in the economy. As a country with the biggest Muslim populace, Muslims in Indonesia are considered to be very concerned about the consumption of halal food. However, the demand for halal food does not necessarily follow the economy of the Muslim population in Indonesia. Therefore, important research has been conducted on consumer behavior when eating halal food. Related research or literature, especially research, or related literature on the influence of religion on consumer behavior is still scarce. This exploration is relied upon to be a reference and produce lawful items just as the adequacy of shopper assurance guidelines, by contrasting the viability of Law No. 23/1992 on Health, Law No. 7/1996 on Food and Law No. 8 of 1999 concerning Consumer Protection, a correlation of Muslim purchaser conduct towards halal items in Muslim larger part and minority regions, as far as determinant elements and parts of legalism, then, at that point, proceeded with the guidelines beneath, specifically Government Regulations. 69 of 1999 concerning Food Labels and Advertisements in Supervision of the Halal Certificate Process and the Labeling Process of Halal Food and Cosmetic Products in Indonesia, the motivation behind this article is to see how Indonesia has turned into the focal point of the halal business. also, give legitimate insurance to Muslim customers in Indonesia and all throughout the planet to remake their economy during the COVID19 pandemic. Therefore, there is the importance of research on consumer behavior in consuming halal food. Related studies or literature, especially regarding the role of religion on consumer behavior, are still minimal. Thus, this research is expected to be
\end{abstract}


useful for the community, both as consumers and producers, as well as the government and other related parties as a reference in formulating policies related to the halal industry, especially processed food products. The method used is descriptive qualitative method, which aims to use active legislation and content analysis techniques for library research to understand various concepts of the research process. The purpose of writing is to find out how Indonesia's role as a mecca for the halal industry is legal protection for Muslim consumers in Indonesia and the world in rebuilding the economy during the COVID-19 pandemic. The strategy utilized is a subjective distinct methodology, which is a work to comprehend the different ideas found in the exploration cycle, utilizing content examination strategies, positive lawful plans, and library research. The strategy they use in this review reasons that Indonesia has standards, kinds of dispersion, and components for halal confirmation, one of which is that makers who apply for halal accreditation should comprise of a progression of tests and present the test results to the Fatwa Committee Officer who chooses the halalness of the product. The aftereffects of the review show that during the COVID19 pandemic, Indonesia's assessment as a modern nation and the halal area can coordinate with the chances for monetary turn of events and government endeavors. With the goal that the public authority, economy, and society can adjust to the new monetary model in this new time of propensities, to push the economy forward during the COVID19 pandemic.

Keywords: Halal certificate; Food Label; Consumer Protection; Descriptive Approach; Fatwa Committee

\section{Introduction}

The improvement of globalization in different fields of economy and lawful guideline has brought about different sorts of products or potentially benefits that can be burned-through. From one perspective, this condition gives advantages to purchasers in light of the fact that their requirements for the ideal products and additionally administrations can be satisfied by their desires and capacities. Then again, this condition makes customers become objects of financial action to produce benefits that hurt buyers. Shoppers are at more serious danger than monetary administrators, that is, buyer freedoms are at more serious danger. Because of shopper shortcomings, buyer freedoms are all the time and effortlessly abused. Then again, purchasers should be ensured by law, since one of the nature and motivation behind law is to secure people in general. Local area security should be as legitimate conviction which is the right of customers [1]. The arrangements of article 1 passage 1) of the Consumer Protection Law no. 8 of 1999, hereinafter alluded to as UUPK. It is expressed that it is accentuated that customer insurance is all endeavors to guarantee wellbeing.

Fortifying the structure of the nobility of shoppers, it is important to build the mindfulness, information, care, capacity and freedom of customers to ensure themselves and foster the demeanor of capable financial entertainers. to guarantee the execution of shopper security. In the arrangements of Article 8 Paragraph (1) of the Law on Consumer Protection Number 8 of 1999 concerning Consumer Protection, it is clarified the preclusion for business people; This arrangement serves to shield customers from misrepresentation by business visionaries and to give legitimate insurance to purchasers. This buyer security is an assurance that buyers should 
acknowledge for each. purchased from manufacturers or entrepreneurs. But in reality, consumers are like the stepson of producers or economic actors. The consumer protection law has been approved, but has not been maximized in the implementation or application of the law itself or the regulations contained in the law are not in accordance with reality. In several cases, many violations were found that harm consumers, which of course refers to the responsibility of economic actors at a level that is considered to endanger the health and even the lives of consumers. For example, non-halal products on the market, (Nucleic Acid) pork, it was found that Viostin DS products have been shown to react positively to pork DNA," the POM Agency wrote. If a product with pig DNA, namely chondroitin sulfate, is imported from a foreign supplier and is used in the manufacture of a certain batch, subsequently contains impurities according to scientific principles, the product automatically contains pork or pork elements. Producing various types of products, especially those that can be consumed by the public. Furthermore, during the free trade period, there is more space for economic actors to produce and market their products, as well as facilitate the entry of foreign products into Indonesia that are not guaranteed to be halal, because the packaging does not include Halal. label, indicating that the authorities have not monitored it. Therefore, supervision must be carried out for all industries, both small, medium and large industries. Because the losers are consumers, especially Muslim consumers. He already had to spend a lot of money to buy to help with his illness, but they gave him a waiver.

With the increasing variety of food products, medicines, and cosmetics, consumers choose various types and quality of these products based on their needs and desires. On the other hand, there is no definite guarantee for this product for Muslims to create consumers whose majority of the Indonesian population is closed. As a country with a Muslim majority population, the Indonesian people demand great responsibility from the government in maintaining the circulation of, Both in terms of taste, sanitation hygiene, good nutritional value and harmful to the body and can be found halal. In the Consumer Protection Law Number 8 of 1999 it is stated that the rights of consumers are the rights to comfort, security, and protection when consuming goods and/or services.

This law shows that all shoppers, including Muslims, reserve the option to get products or potentially benefits that are helpful for them to burn-through. As per article 1 passage 5 Government Regulation no. 69 of 1999 concerning Food Labels and Advertisements, states: "Halal food will be food that doesn't contain components or fixings that are taboo for Muslims or whose utilization is disallowed, be it food unrefined substances, food added substances or food added substances, food items, food added substances, and food added substances. materials and other assistant materials, including food fixings, which are handled through hereditary designing and food water system and which are managed in understanding with the provisions of Islamic law flowing locally that are not as per the provisions of Islamic law. Official guidelines might force sanctions on monetary entertainers, including the sanctions directed in Law Number8 of 1999 concerning Consumer Protection. the objective is to guarantee wellbeing and congruity coursed so buyers are not hurt.

\section{Problem Formulation}

How tightening regulations on halal labelling have protected Muslim consumers in Indonesia as a global sector of halal products worldwide. The urgency of this research are:

1. The first step is to find an effective and tested method of applying consumer protection law in consumer protection against the discovery of non-halal cosmetic products in order to 
create legal order and justice as regulated by Law No. 8/1999 on consumer protection.

2. As a solution to provide more insight and transparency for the wider community to find out halal food and cosmetic products, create justice for fellow consumers or traders about whether or not product information is halal so as to create healthy competition.

This research was conducted using a novice lecturer research scheme because it will be carried out by novice lecturers and is a study material based on social reality problems that occur in society, so that the results of this research can be implemented.

\section{Method}

In writing this research, the author conducts research using a normative juridical approach which will discuss it from the point of view of the applicable laws and regulations. The research method used is the research and development model of Borg and Gaal (2003) and is planned for one year of activities as follows:

1. preliminary research, including needs analysis, literature study.

2. Plan advancement (foster fundamental of item) incorporates the plan of a lawful insurance model for purchasers through Halal Certification in Food and Cosmetic Products

3. Initial field testing (preliminary field testing), was carried out in several institutions such as the Indonesian Ulema Council LPPOM and the Indonesian Consumers Foundation. This trial preceded by (training of tutorial staff, (2) preparation of trials, including targeting for interviews, time and place of implementation (3) implementation of trials, and (4) trial evaluation.

Revision of the results of the trial (main product revision), using FGDs with the involvement of experts from the discipline of Business Law who are concerned in the field of Consumer Protection Law. Eventual outcome update is a model of lawful security for shoppers through halal certificate for food and corrective items. To get the necessary information the creator will utilize the accompanying information assortment techniques:

\subsection{Using Primary Data}

In this case the authors collect data by means of direct interviews with the MUI and the Indonesian Consumers Foundation.

\subsection{Using Secondary Data}

For this situation the writers gather information by looking into, perusing and auditing books, guidelines, writing, logical works that have a relationship with the Implementation of Legal Protection Against Consumers Through Halal Certification in Food and Cosmetic Products, other than that FGD will likewise be directed to define the underlying and last ideas.

The method used to analyze the data is descriptive analysis, i.e the data obtained are then compiled systematically and then analyzed descriptively to achieve clarity of the problems to be discussed coupled with observation, juridical analysis that will be carried out as users of cosmetics, women are most often made to worry about ingredients. The identified hazardous substances are in cosmetics, one of which is mercury. Ignorance makes women confused to distinguish whether the cosmetics used contain mercury or not.

"Mercury, also known as Mercury, is a chemical that can be found as an additive in skin lightening soaps and creams, as well as a preservative in cosmetic products." 
In Indonesia, the utilization of mercury in these items has been precluded dependent on the Regulation of the Minister of Health Number 1175/Menkes/Per/VIII/2010 of 2010 concerning Cosmetics Production Permits. Then, at that point, it was explained in the Regulation of the Head of the Drug and Food Control Agency (hereinafter shortened to BPOM) RI Number 17 of 2014 concerning Amendments to the Regulation of the Head of BPOM Number HK.03.1.23.08.11.07517. In 2011 concerning Requirements for Microbial and Heavy Metal Contamination in Cosmetics, it was explained that the requirements for heavy metal contamination in cosmetics for mercury $(\mathrm{Hg})$ should not be more than $1 \mathrm{mg} / \mathrm{kg}$ or $1 \mathrm{mg} / \mathrm{L}$ (1bpj). Then rumors circulated about how to test cosmetics containing mercury using gold jewelry, whether rings, necklaces or bracelets, which were widely spread on social media.

This method is done by applying cosmetics to the back of the palm and then rubbing it with gold that we have, if the cosmetic product that is applied turns black, then the cosmetic contains mercury. The products that are usually tested are face powder or cream.

"In the case mentioned above that there are some chemicals, whether harmful or not, when tested or tested by being dropped with metal, they can react to change color, this color can be called the reaction color. However, it was emphasized that it is not that easy to test the mercury content in cosmetic products, because testing the mercury content can only be done through laboratory testing using an Atomic Absorption Spectrometer whose process is through burning the sample first so that it can then be detected."

In addition to the issue of the hazardous substance mercury found in cosmetics, there are also issues regarding alcohol which is commonly found in cosmetic products, especially for facial or eye cleansers.

"In science liquor or alkanol is an overall term for any natural compound that has a hydroxyl bunch (- OH) attached to a carbon molecule, which is itself clung to a hydrogen iota and additionally another carbon particle."

Alcohol is a common substance used in the pharmaceutical and cosmetic industries, primarily as a solvent. What is the status if the cosmetics we use contain alcohol and what are the criteria for these cosmetics to still be categorized as halal cosmetic products. When it comes to alcohol, what is actually forbidden is khamr, alhokol; "itself is a chemical group. When talking about the chemical groups of alcohol, there are many, starting from methanol, ethanol, butanol, and others."

Generally speaking, the alcohol that is often found in the industry is ethanol, this ethanol is not absolutely khamr, because in principle in the certification process when finding alcohol or ethanol, it is necessary to ensure that the ethanol comes from the khamr industry or not.

"For cosmetics, there is no limit to the amount of ethanol that must be present or allowed in a cosmetic product. It is different from ethanol in drinks, because usually the ethanol contained in these drinks is created due to process conditions or for example there is one ingredient whose solvent may be ethanol. If in the beverage product there is a permissible limit, a maximum of $0.5 \%$." So actually in this certification process, the use of ethanol is allowed, but with the following conditions:

1. Ethanol does not come from the khamr industry or the liquor industry. If ethanol is in beverage products that can be drunk directly, the ethanol content used should not be more than $0.5 \%$.

2. Apart from ethanol, ingredients that are definitely haram are all those related to pork. Not only products that clearly contain pork, the Fatwa of the Indonesian Ulema Council (hereinafter shortened as MUI Fatwa) Number 26 of 2013 concerning Halal Standards for Cosmetic Products and Their Use additionally reminds that corrective items that utilization fixings from microbial items whose microbial development media are not known whether 
from pigs, ought to be stayed away from until there is clearness about the halalness and immaculateness of the fixings.

"For materials from animals such as placenta, the status is halal as long as the placenta comes from halal animals. This means that placentas from animals such as cows, goats, buffalo, and horses are allowed, but this is not the case if the placenta comes from pigs or dogs. Human placenta is also haram. In addition to animal species, MUI also forbids placentas taken by live animal fetuses."

"If hazardous chemicals are found in cosmetics that are labeled halal, it is necessary to first ensure that the product referred to as halal is labeled halal from the MUI or not. Because on the market there are still many halal labels that are not official MUI."

When the halal label is not from the Indonesian Ulema Council, the product declares the product halal by itself so that it includes a halal label or if the product is imported it gets a halal certificate from an outside institution. Basically, when you want to include a halal label on the packaging for products sold in Indonesia, you must have obtained permission from BPOM.

Based on the information above, it can be seen that the inspection carried out by MUI starts from examining administrative documents, documents regarding the halalness of raw materials, information related to products to direct inspections at the production site to ensure that the written information provided by the manufacturer is in accordance with the conditions at the production site. The norms contained in some of these provisions indicate that business actors should know that it is forbidden to trade goods that do not follow Islamic law and must be responsible for everything/everything that is traded. But in reality, there are still products and foods that do not have halal certificates/labels. Halal labeled products are intended to provide comfort and safety for every consumer who uses or consumes products and food [5].

The consequence of the existence of regulations related to the inclusion of labels as mentioned above is that every business actor that produces food, beverage, drug and cosmetic products is required to include a sign containing the ingredients used and the composition of each ingredient in the product. Information related to the composition of ingredients in the production of a product can be used as a medium for Islamic consumers to observe the product. If in the statement there is a composition which is essentially haram in the perspective of Islamic law, then it becomes imperative for Islamic consumers not to consume it.

The urgency of the provision of signs or labels for Islamic consumers is to inform the composition of a food product primarily to consumers who are Muslim. Thus, consumers who are Muslim can observe the composition of a product that they want to consume. The establishment of the Halal Product Guarantee Act in principle aims to protect consumers from consuming certain products that are contrary to their beliefs. Therefore, every business actor who produces or imports food into the territory of Indonesia that is packaged for trading must include a label on the food packaging. In addition to the obligation to include a label on the list of materials used, business actors are also to provide halal information on the product. Informing the list of ingredients used can help consumers know the composition used in the product production process, before consumers decide to buy certain food products. The information related to halal information is intended so that Muslim consumers know the halal status of the product to be consumed.

Prior to the enactment of Law no. 33 of 2014, the halal certificate of a product is based on a halal certificate issued by LPPOM MUI. Halal certificate is a certificate issued by the Central or Provincial MUI regarding the halalness of a food, beverage, drug and cosmetic product produced by a company after being examined and declared halal by LPPOM MUI [6]. 
Business entertainers prior to applying for a halal authentication should set up a Halal Assurance System which alludes to the Guidebook for the Preparation of a Halal Assurance System gave by LPPOM MUI. LPPOM MUI names one or a group of inner inspectors halal who is answerable for guaranteeing the execution of halal items. Marking an ability to be reviewed out of nowhere without earlier warning by LPPOM MUI. make occasional reports like clockwork in regards to the execution of the Halal Assurance System. Makers apply for a halal testament to the LPPOM MUI secretariat by finishing up a structure, enrolling all items created including creation areas, bundling processing plants and places to eat, for eateries and obliging register all menus sold, outlets, kitchens and stockrooms. For Slaughterhouse Producers should enroll all spots of slaughter. Each candidate who applies for a halal endorsement for his item, should finish up the structure containing data about organization information, the sort and name of the item and the materials utilized. The finished structure and its supporting archives are gotten back to the secretariat. LPPOM MUI actually looks at its culmination and in case it isn't adequate the organization should finish it as per the arrangements. LPPOM MUI reviews. The review group conducts investigations/reviews at the maker.

The consequences of the assessment/review and research facility results (in case essential) are assessed in the LPPOM MUI examiner meeting. Review results that don't meet the prerequisites are informed to the organization. If it meets the necessities, the inspector will make a report on the consequences of the review to be submitted to the MUI Fatwa Commission meeting. The MUI Fatwa Commission meeting might dismiss the review report, in case it is considered not to have satisfied every one of the necessities and the outcomes will be submitted to the maker who is applying for halal confirmation. Halal authentications are given by the Indonesian Ulema Council after their halal status has been dictated by the MUI Fatwa Commission. Halal authentications are legitimate for 2 (two) a long time from the date of fatwa assurance right now.

\subsection{Data Collection}

The method used to analyze the data is descriptive analysis, ie the data obtained are then compiled systematically and then analyzed descriptively to achieve clarity of the problems to be discussed plus observation, juridical analysis to be carried out. Based on the issues that develop in the community, it is expected that consumers Be smarter and do a research check every time you get a chain message. Buy cosmetic products that have received a distribution permit from the BPOM of the Republic of Indonesia or from a beauty specialist who has a practice permit. In addition to emphasizing that cosmetic ingredients must be halal and holy, as well as interests that are permitted by sharia, MUI also emphasizes that the use of cosmetics should not be harmful. 


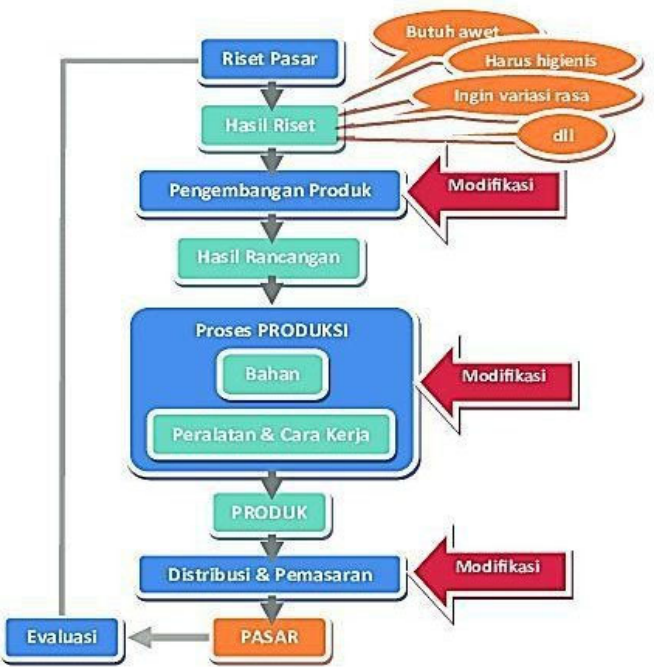

Fig. 1. Procedure for Submitting LPPOM MUI Halal Certification

Based on the information above, it can be seen that the inspection carried out by MUI starts from examination of administrative documents, documents of halal raw materials, product-related information to direct inspection at the production site to ensure that the written information provided by the manufacturer is in accordance with the conditions at the production site. The following is a breakdown of the completeness of registration for each industry group:

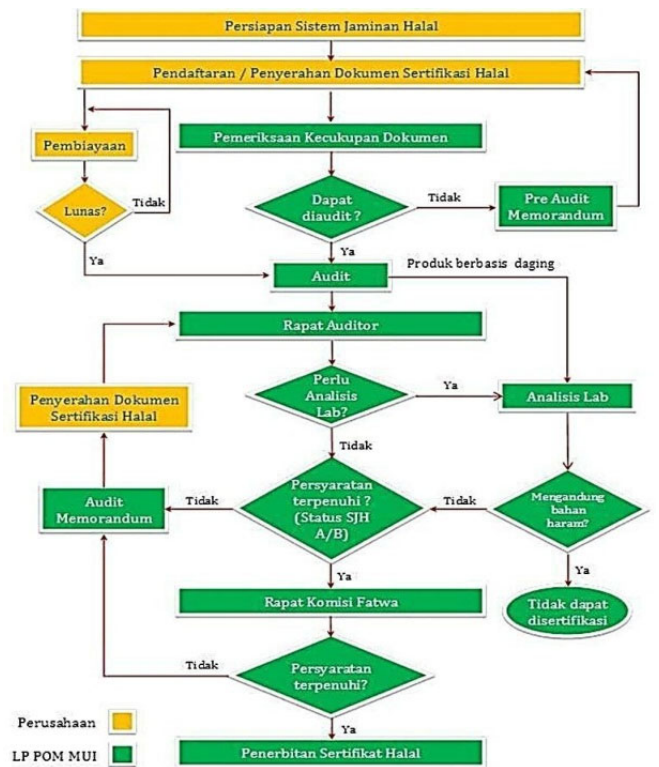

Fig. 2. For the processing industry 
Makers should enlist all items delivered in a similar area or potentially which have a similar brand/brand.

1. Makers should enroll all creation locales including ringing and bundling processing plants.

2. Arrangements for ringing places should be completed in organizations that as of now have halal-ensured items or will be halal-affirmed.

For restaurants and caterers:

a. Eateries and food providers should enroll all menus sold, including store items, birthday cakes and occasional menus.

b. Eateries and caterers should enlist all outlets, kitchens and stockrooms.

c. For abattoirs:

Producers must register all places of slaughter that are in the same company. In the event that an indication of the content of non-halal materials or processes in production is found by the auditor team, the producer is given the opportunity to improve the material or process through written notification or by telephone call by the MUI, if the producer neglects or does not meet the requirements for perfection, the auditor team through LPPOM MUI, report in writing the results of the audit to the MUI fatwa trial to decide on the halal status of the product being applied for.

Procedures for inspection (audit) of halal products include:

1. Production management in ensuring product halalness (halal assurance system).

2. Inspection of specification documents

3. Field observations covering the entire production process from material receipt, production, packaging and storage to restaurant / catering / point of sale service. The validity of the documents and the physical suitability of each ingredient must be met.

4. Sampling is done for materials that are deemed necessary. 112 manufacturers who have successfully passed several of the above procedures will receive a Halal certificate and this certificate is the legal basis for any manufacturer to print Halal labels on any food or beverage packaging they manufacture and market. The certificate is valid for 2 (two) years from the date the fatwa is established. In order to receive a Halal certificate, manufacturers must 3 (three) months before requesting a certificate renewal.

\section{Results and Discussion}

Investigation of fortifying laws and guidelines overseeing halal names identified with the insurance of Muslim buyers in Indonesia The truth that individuals, the Indonesian public, around $90 \%$ of them are Muslim customers. Along these lines, food handling should be considered for $90 \%$ of the Indonesian populace, with the goal that it is by implication moderately alright for customers other than Indonesian Muslims. For Muslim shoppers, safe food isn't just liberated from physical, synthetic or microbiological risks, yet in addition has an extremely fundamental component, in particular being protected from the risks of precluded and problematic merchandise. Sanitation, quality and sustenance as ordered by the Food Law no. 7 of 1996, is an administration food advancement work to meet the fundamental necessities of the Indonesian individuals in a reasonable and impartial way., in light of freedom and not against public conviction. Food handling perils delegated "illicit or potentially sketchy" destructive impacts don't have all the earmarks of being as old as, physical and microbiological tainting impacts that straightforwardly influence medical conditions. The risk of this halal class affects the true serenity of Muslim purchasers and when 
4,444 Muslim customers devour non-halal food items, the effect of the misfortunes caused is unavoidable, very enormous, specifically Muslim buyers feel awkward in their spirits. since they burn-through non-halal food items and this misfortune is unavoidable. The significance of the legitimate parts of medication and food naming, combined with expanding purchaser requests, particularly identified with this halal viewpoint. Legitimately, this issue has been settled by the public authority both in the Food Law, customer security laws and more specialized unofficial laws direct halal affirmation of food items. Alongside the presence of halal certificate on food items devoured by general society, it is one of the public authority's endeavors to ensure $90 \%$ of the Muslim shopper local area, however deciding from public trust, the naming of these food items.

The rules contained in some of these provisions indicate that economic operators must know that the trade in goods that do not comply with Islamic law is prohibited and they must be responsible for everything that is traded. But in reality there are still products and foods that do not have a Halal certificate / label. Halal certified products are designed to provide comfort and safety to all consumers who use or consume products and food.

The existence of the previous regulations for the inclusion of labels means that every entrepreneur who manufactures food, beverages, pharmaceuticals and cosmetics must place a sign with the ingredients used and the composition of each product. Information on the composition of ingredients in the manufacture of a product can be used as a means for Islamic consumers to observe the product. If the statement contains a composition that is essentially haram from the point of view of Islamic law, it becomes imperative for Islamic consumers not to consume it.

The urgency of providing signs or labels to Islamic consumers is primarily to inform Muslim consumers about the composition of a food. In this way, Muslim consumers can observe the composition of a product they want to consume. The introduction of the Halal Products Guarantee Law has as its fundamental objective to protect consumers from consuming certain products that contradict their beliefs. Therefore, any economic operator that manufactures commercially packaged food or imports it into the territory of Indonesia must put a label on the food packaging.

In addition to the obligation to include a label in the list of materials used, economic operators are also obliged to provide Halal information on the product. Information on the list of ingredients used can help consumers to know the composition used in the manufacturing process of the product before consumers decide to buy certain foods. Information on Halal information is intended to make Muslim consumers aware of the Halal status of the product.

Before the entry into force of Law 33 of 2014, the Halal certificate of a product is based on a Halal certificate issued by LPPOM MUI. The Halal Certificate6 is a certificate issued by the Central or Provincial MUI of the halality of a food, beverage, pharmaceutical and cosmetic product manufactured by a company after it has been examined by LPPOM MUI and declared halal issued by LPPOM MUI.

LPPOM MUI appoints a person or team of Halal internal auditors who is responsible for ensuring the implementation of Halal products. Signature of availability for inspection suddenly without prior notice by LPPOM MUI. Report periodically on the implementation of the Halal security system every 6 months.

Manufacturers apply for a Halal certificate at the LPPOM MUI Secretariat by completing a form, recording all products produced, including production sites, packaging factories and dining areas, recording all menus sold, outlets, kitchens and warehouses for restaurants and catering. For slaughterhouse producers, all slaughterhouses must be registered.

Any candidate mentioning a Halal testament for their item should finish the structure with 
the data of the organization, the sort and name of the item and the materials utilized. The finished structure and related records will be gotten back to the secretariat. LPPOM MUI actually looks at the trustworthiness and in case it isn't sufficient, the organization should finish it as per the guidelines. LPPOM MUI reviews The review group performs examinations/reviews at the producer's site and, at the hour of the review, the organization should have the option to make ensured items. Test/review results and, if pertinent, research center outcomes are assessed at the LPPOM MUI inspector meeting. The consequences of the review that don't meet the necessities are conveyed to the organization. If you meet the prerequisites, the examiner will set up a report on the review results, which will be introduced to the MUI Fatwa Commission meeting. The MUI Fatwa Commission meeting might dismiss the review report in the event that it accepts that it doesn't meet every one of the necessities and the outcomes are introduced to the producer applying for Halal accreditation. The Halal testament is given by the Ulema Council of Indonesia after the MUI Fatwa Commission has set up Halal status. The Halal testament is substantial for 2 (two) a long time from the date of the fatwa. As of now, the application for the Halal authentication should be possible. The Halal testament is given by the Ulema Council of Indonesia after the MUI Fatwa Commission has set up Halal status. The Halal testament is substantial for 2 (two) a long time from the date of the fatwa. As of now, the application for the Halal authentication should be possible. The Halal testament is given by the Ulema Council of Indonesia after the MUI Fatwa Commission has set up Halal status. The Halal testament is substantial for 2 (two) a long time from the date of the fatwa. As of now, the application for the Halal authentication should be possible.

\section{Conclusion}

The laws and guidelines administering the fastening of halal marks don't give insurance to Muslim purchasers, in light of the fact that the commitment to remember nourishment for bundling isn't a commitment, yet all at once just intentional. The command of the Food Law Number 18 of 2012 concerning Food Safety, Quality and Nutrition is a work the public authority in creating food to meet the essential necessities of the Indonesian individuals in a reasonable and impartial way, in light of confidence and not in opposition to public convictions. Notwithstanding, if food dissemination is still forward-thinking or can be created, the assurance of Indonesian Muslim customers isn't yet clear how to control it to guarantee the solace and security of shoppers in Indonesia.

The procedure flow for the inclusion of halal labels on packaged foods is starting with product registration to LPPOM MUI to be examined and investigated regarding the halalness of the product, starting from raw materials, auxiliary materials and additional materials used for equipment and transportation must not be contaminated with goods that are not halal for the public. Muslim consumers, and if LPPOM MUI based on research states that the packaged food product that has been registered is halal, then LPPOM MUI issues a halal certificate, then this halal certificate from MUI is used as the basis for the inclusion of halal labels on packaged food products.

The presence of halal certification has become a must for all food products in circulation and there are no regulations that require it. This certificate is a prerequisite for receiving the Halal label. The reality in this area is that Halal certification can be issued if the producer wants and is willing to review the production process. As a means of information for producers, MUI has issued guidelines for obtaining Halal certificates. What happens if a producer does not want their production process to be verified as a condition for obtaining a 
Halal Certificate? There is no legal sanction if the producer does not want the production process to be verified.

and after LPOM MUI examines and decides that the packaged food product is halal, a new Halal Certificate will be issued and the Halal Certificate issued by LPOM MUI will be used as the basis for placing the Halal label on the LPOM MUI packaged food. They do not want to receive a Halal certificate for the packaged food they produce, therefore there are no applicable legal provisions that provide sanctions, because the Halal certificate is not mandatory.

The power of LPOM MUI to give halal declarations depends on the arrangement of the Decree of the Minister of Religion of the Republic of Indonesia Number 519 of 2001 dated November 30, 2001 concerning the Implementing Institution for Halal Food Inspection, in Article 1, decides: to be exchanged Indonesia.

Consequently, the laws and guidelines administering halal naming, for example, Law Number 8 of 1999 concerning Consumer Protection (UUPK), Law Number 18 of 2012 concerning Food, Government Regulation of the Republic of Indonesia Number 69 of 1999 concerning Food Labels and Advertisements have not given lawful sureness and legitimate security for Muslim purchasers in burning-through halal food items, the Republic of Indonesia as a country that has the biggest extent of residents and inhabitants who are Muslim, gives assurance and ensures lawful insurance for Muslim buyers.

\section{References}

[1] Barkatullah, Abdul .im. Consumer Rights. Nusa Media, Press 1, Bandung (2010)

[2] Marzuki, Peter Mahmud. Legal Research. Kencana Prenada Media Group, Jakarta (2010)

[3] Ahmadi Miru and Sutarman Yodo, Consumer Protection Law, (Jakarta: PT. Rajawali Pers, 2011), 4-6.

[4] Siradjuddin, Azmi. Food Regulations in Indonesia. Tapis Vol. XIII, No. 01 JanuaryJune (2013)

[5] Law Number 33 of 2014 concerning Product Assurance

[6] Ministry of Religion RI. Technical Guidelines for Production System Guidelines. Ministry of Religion of the Republic of Indonesia, Jakarta (2003)

[7] Subagyo, Joko. Research Methods in Theory \& Practice. Rineka Cipta, Jakarta (2006)

[8] Sukarmi. Cyber Law: Electronic Contracts in the Shadows of Business Actors. Pustaka Sutra, Bandung (2008)

[9] Subagyo, Joko. Research Methods In Theory \& Practice. Rineka Cipta, Jakarta (2006)

[10] Nurhayati, Resti. Consumer Protection Based on Law Number 8 of 1999. Legal Grid of the Scientific Magazine of FH Soegijapranata, IX Edition, p. 38. Semarang (2001)

[11] Hasan, Sofyan, et al,. Certification in Positive Law, Regulation and Its Implementation in Indonesia. Aswaja Pressindo, Yogyakarta (2014)

[12] Numardjito. "Readiness of Legislations on Consumer Protection in Indonesia," in Husni Syawali and Neni Sri Imaniyati. Editor. Consumer Protection Law. Mandar Maju, Bandung, p. 18 (2000)

[13] Law Number 8 of 1999 concerning Consumer Protection (UUPK).

[14] Az. Nasution. Consumer Protection Law An Introduction. Diadit Media, Jakarta, (2001)

[15] Amin, Ma'ruf. Fatwa Products .al Protecting and Peaceful. Journal Library, Jakarta, p. 
$97(2010)$

[16] Government Regulation of the Republic of Indonesia Number 69 of 1999 concerning Food Labels and Advertisements

[17] Food Law Number 18 of 2012 concerning Food Safety, Quality and Nutrition

[18] Decree of the Minister of Religion of the Republic of Indonesia Number 519 of 2001

[19] Sincere Timeless Etc. Legal Assessment Team on Community Participation in Providing Information eg, Ministry of Law and Human Rights National Legal Development Agency, Jakarta (2011)

[20] Fatwa of the Indonesian Ulema Council (hereinafter abbreviated as MUI Fatwa) Number 26 of 2013 concerning Halal Standards for Cosmetic Products 